\title{
SCIENTIFIC BASIS OF THERMAL SAFETY ANALYSIS OF DRY STORAGE OF SPENT NUCLEAR FUEL ON ZAPORIZHSKA NPP
}

\author{
S. Alyokhina ${ }^{1,2}$, A. Kostikov ${ }^{1}$, I. Koriahina ${ }^{2}$ \\ ${ }^{1}$ A. Podgorny Institute of Mechanical Engineering Problems of the National Academy \\ of Sciences of Ukraine, Kharkiv, Ukraine \\ E-mail: alyokhina@ipmach.kharkov.ua,tel.+38(057)294-27-94; \\ ${ }^{2}$ V.N. Karazin Kharkiv National University, Kharkiv, Ukraine
}

\begin{abstract}
Now only one Dry Storage Facility of Spent Nuclear Fuel (DSFSNF) is operated in Ukraine. It is the facility on Zaporizhska NPP. Many different thermal investigations were done for ventilated containers of DSFSNF. In this study the generalization of scientific approaches to the thermal safety assessment are carried out. The multi-stage approach to the definition of thermal state of containers' group, single container, spent fuel assemblies and fuel rods was developed. Detailed thermal profiles of spent fuel assemblies inside storage container were calculated. With usage of multi-stage approach the thermal simulations of the influence of outer factors onto thermal state of containers was carried out. Results of thermal investigations were generalized and factors, which are influence on thermal state of containers, are detected. The method of spent nuclear fuel thermal state prediction and suggestion for improving the system of thermal monitoring were proposed.
\end{abstract}

PACS: 47.27.te

\section{INTRODUCTION}

Ukraine has more than 15 years of experience to store spent nuclear fuel (SNF) of power reactors. The fuel from 6 WWER-1000 reactors of Zaporizhska NPP is stored by the dry method on the open-air platform in ventilated containers (Fig. 1).

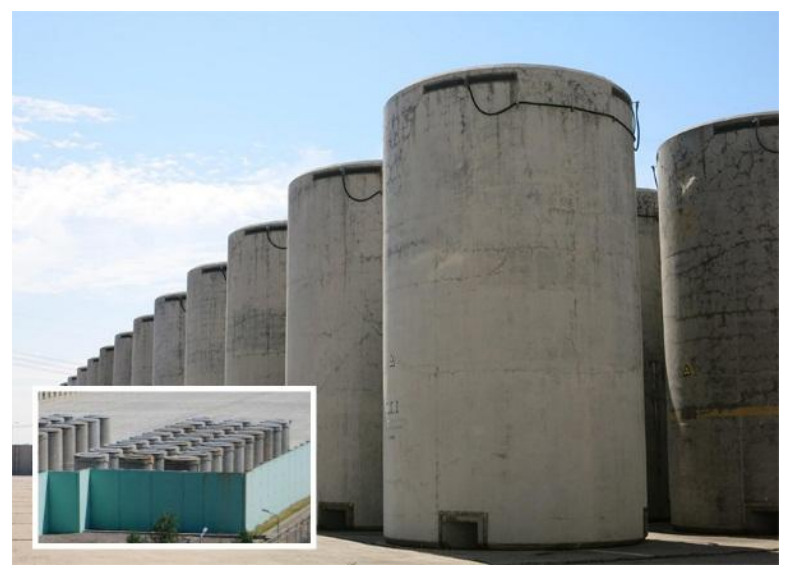

Fig. 1. Storage containers of Zaporizhska NPP

Since 2001 when the first container with SNF was located on the storage platform, the thermal monitoring of the state of containers is performed. The thermal monitoring is carried out by measuring the ventilating air temperature (Fig. 2). One of the main criteria of safeoperation of SNF storage container is that air is heated in the ventilation duct not more than 61 celsius degrees [1].

Long and safe operation of any nuclear facility such as the Dry Storage Facility of Spent Nuclear Fuel (DSFSNF) on Zaporizhska NPP is not possible without its scientific support. The scientific support implies it is understood the deep and system analysis of physical processes during facility operation with detecting and structuring factors of influence on the state of SNF, and development of methods of effective safety control and improvement.

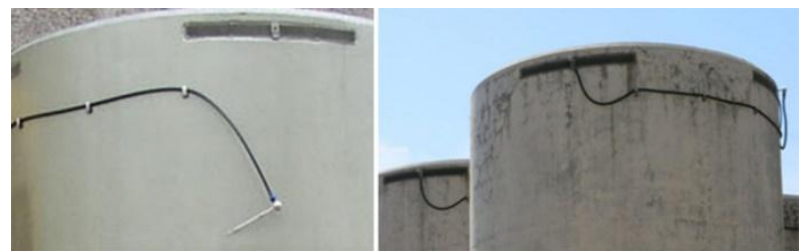

Fig. 2. Resistance thermometer and the place of its location in the system of thermal monitoring

There are lot of research works dedicated to the problems of estimation radioactive emission and its influence onto humans and environment [2, 3], calculation of subcriticality and prevention of the uncontrolled chain reaction [4], development additional radiation protection constructions etc. However, the thermal part of the complex concept of DSFSNF safety has not enough scientific attention. Traditional approach in the thermal safety assessment is the single thermal calculations on stage of the basic equipment development. Moreover, usually these calculations have a lot of simplifications and averaging with purpose to ensure enough safety margins at operation. Although this approach is accepted at normal operation of DSFSNF it does not give full information about thermal processes at the dry storage. This limitation does not allow effectively increase safety level of the storage or develop approach for equipment modernization, which could be caused by commercial competition in the nuclear waste management.

It should be noted that studies of thermal safety of the dry spent nuclear fuel storage were carried out by some researchers [5-9]. All studies, as a rule, carried out in three main topics: normal and accident operation conditions studying, and studies focused on improvement of the storage equipment. The main feature of existing scientific works is an absence of the thermal simulation results generalization, classification of factors, which have influence onto the thermal state of the spent nuclear fuel and storage equipment, and general approach to the SNF thermal state simulation and identification. 
This paper is devoted to the analysis of the thermal processes on the dry SNF storage facility of Zaporizhska NPP.

\section{METHODOLOGY}

The specificity of containers with SNF does not allow to simulate directly their thermal state. Large differences between characteristic sizes (for example, height of fuel rod and its diameter) require high quality meshing, so computational time increases and there is a need to use high speed computers clusters. The most sensible way to avoid this is dividing the computational area to the parts, solving thermal problems for each of themand then connecting results. The iterative methodology for the thermal state simulation is presented on Fig. 3.

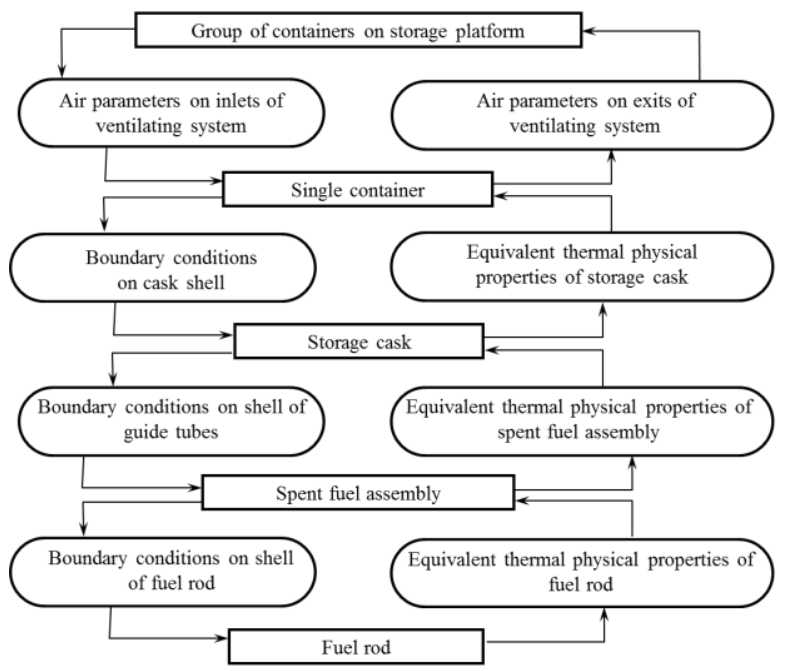

Fig. 3. Iterative methodology of the SNF thermal state definition

According to itateach level of calculation procedure some part of computational domain is replaced by simplified objectand the boundary conditions on its surfaces are calculated. At the next level of calculation procedure this part is simulated in detailed structure. This approach was described in details in [10].

Verification of results, which are obtained with usage described approach, was carried out by comparison of measured temperature of ventilation air in outlet vents and calculated one. The difference between these two values are not more than $3 \%$.

Simulation was done for beginning of the SNF storage. So, the decay heat of each fuel assembly was fixed as $1 \mathrm{~kW}$ according to [11].

\section{RESULTS}

Results of modelling of the thermal state of containers group with usage of described approach are shown that there is no mutual thermal influence between them. Heated air flows freely out of container and doesn't get into the ventilation duct of neighbouring containers (Fig. 4).
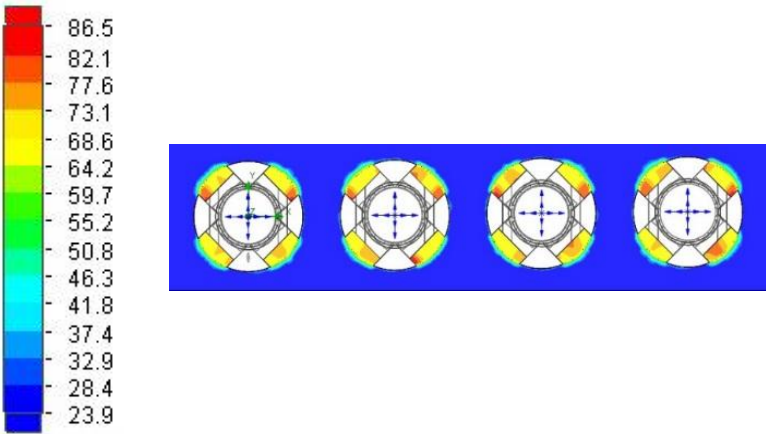

Fig. 4. Temperature profile of air for containers group

With usage of the described approach the detailed thermal profiles of the SNF inside ventilated storage container were calculated. Fig. 5 shows the temperature profiles of the container and storage cask with spent fuel assemblies.
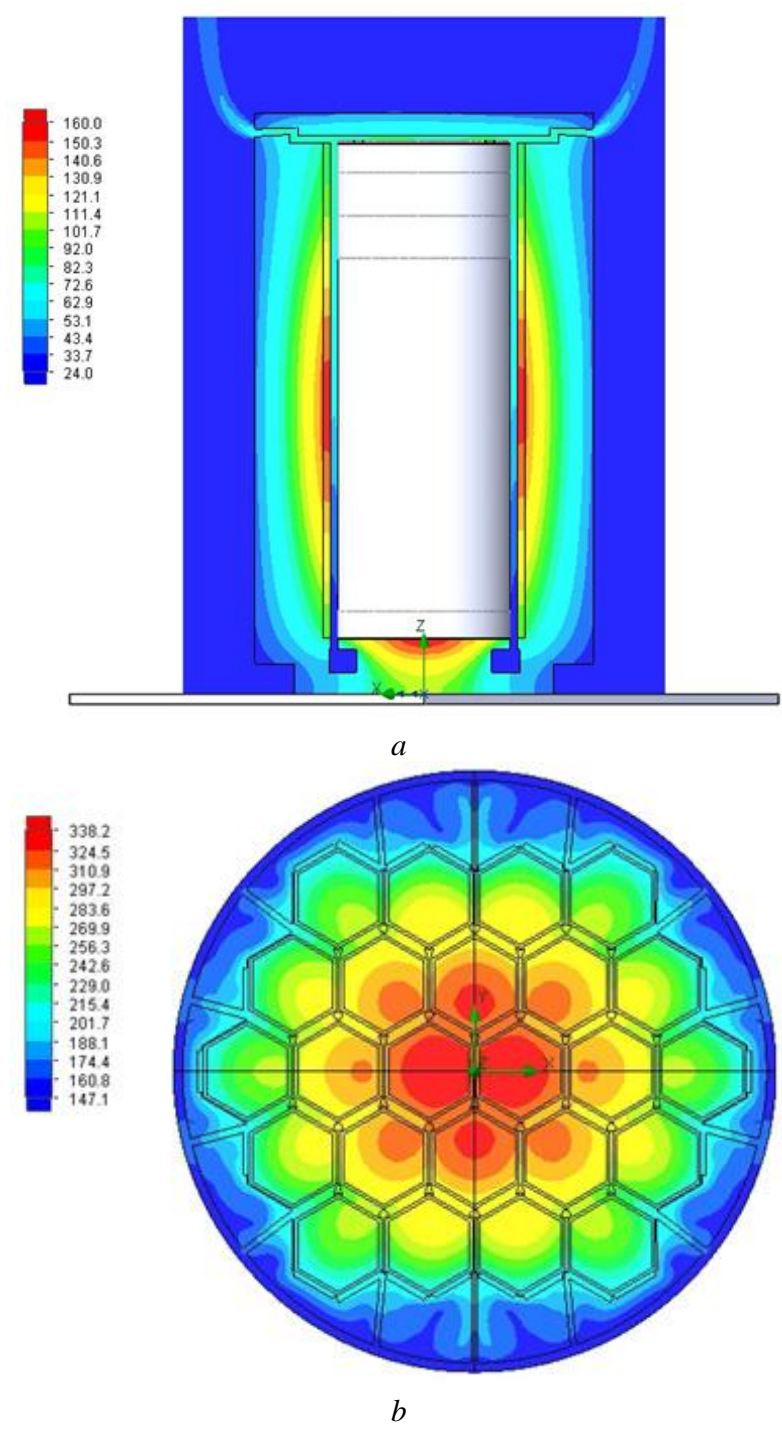

Fig. 5. Temperature profile of the storage container (a) and storage cask $(b)$

All factors of influence on the thermal state of storage containers with SNF (for example, like described in [12]) could be classified on basis of their character (Fig. 6). The part of these factors appears at accident conditions, other at normal operation. 


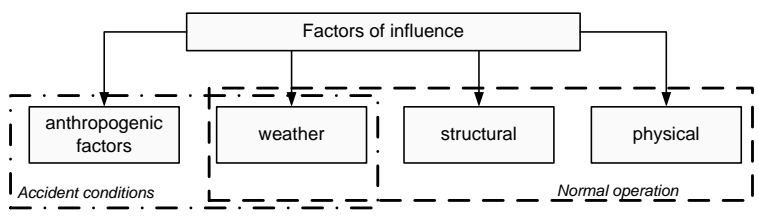

Fig. 6. Classification of the factors, which have influence on the thermal state of SNF

The physical factor of influence (decay heat) and weather factor (temperature of atmospheric air) must be taken into account at calculation (prediction) of the maximum temperature inside storage container. The analysis of the results of simulation allows to find the functional dependences of the maximum temperature in storage container $\left(T_{\max }\right)$ and the temperature of the vent air $\left(T_{\text {exit }}\right)$ on the decay heat $(Q)$ and temperature of atmospheric air $\left(T_{a}\right)$ :

$$
\begin{aligned}
& T_{\max }=26.96+0.74 T_{a}+0.014 Q-0.0036 T_{a}^{2}- \\
& -1.141 \cdot 10^{-7} \mathrm{Q}^{2}+1.07 \cdot 10^{-5} T_{a} Q ; \\
& T_{\text {exit }}=8.13+0.8694 T_{a}+0.002 Q-0.00085 T_{a}^{2}{ }^{-} \\
& -1.432 \cdot 10^{-8} \mathrm{Q}^{2}+6.116 \cdot 10^{-6} T_{a} Q .
\end{aligned}
$$

These dependences are reasonable to be used at thermal monitoring of SNF storage for control measured parameters. It is especially actual during the last years of storage when decay heat of SNF is low hereupon criterion limit in 61 celsius degreesof air heating is never reached. So, the measured temperature of ventilating air must be compared with calculated temperature of ventilating air with purpose to detect air heating increasing and probable accident.

Other factors of influence onto the thermal state of SNF was investigated in [13] (influence of the daily temperature fluctuations) and [14] (influence of solar irradiation). It is found that both of them are not dangerous for spent nuclear fuel stored inside concrete containers.

\section{CONCLUSIONS}

Scientific support is important part of SNF storage facility operation. Thermal simulations were done for the dry storage containers of the Zaporizhska NPP. Obtained results are significant for the safety analysis and allow to develop safety assessment process on scientific base with taking into account physical nature of processes.

\section{ACKNOWLEDGEMENTS}

Results, which are presented in this paper, were obtained in A. Podgorny Institute of Mechanical Engineering Problems of the National Academy of Sciences of Ukraine (Research Grant No. 15/01-2020) with partial support of International Atomic Energy Agency under SPAR-IV, IAEA Research Contract No. 20605.

\section{REFERENCES}

1. Safety Analysis report for Dry Spent Nuclear Fuel Storage Facility of Zaporizhska NPP. Version 3.01.1. 2008, 624 p.

2. I.I. Zalyubovskii, S.A. Pismenetskii, V.G. Rudychev, S.P. Klimov, A.E. Luchnaya, E.V. Rudychev. External radiation of a container used for dry storage of spent WWER-1000 nuclear fuel from the Zaporozhie nuclear power plant // Atomic Energy. 2011, v. 109, issue 6, p. 396-403; DOI: 10.1007/s10512-011-9374-8.

3. J. Jang, W. Kim, S. Jeong, E. Jeong, J. Park, M. Lemaire, H. Lee, Y. Jo, P. Zhang, D. Lee. Validation of UNIST Monte Carlo code MCS for criticality safety analysis of PWR spent fuel pool and storage cask // Annals of Nuclear Energy. 2018, v. 114, p. 495-509.

4. K. Smith, E. Sykora, G. Gunow, H. Akkurt. PWR fuel reactivity depletion uncertainty quantification - Methods validation tests // Transactions of the American Nuclear Society. 2017, p. 878-880.

5. M.V. Maksymov, O.I. Brunetkin, O.B. Maksymova. Application of a special method of nondimensionization in the solution of nonlinear dynamics problems // Control Systems: Theory and Applications. 2018, p. 97-142.

6. Y.E. Karyakin, V.M. Kuzin, A.A. Pletnev, E.D. Fedorovich. Numerical modeling of the thermal state of a metal-concrete container with spent nuclear fuel during Its transportation // Journal of Engineering Physics and Thermophysics. 2018, v. 91, issue 4, p. 991-998.

7. R. Poskas, V. Simonis, P. Poskas, A. Sirvydas. Thermal analysis of CASTOR RBMK-1500 casksduring long-term storage of spent nuclear fuel // Annals of Nuclear Energy. 2017, N 99, p. 40-46; DOI: 10.1016/j.anucene.2016.09.031.

8. R.D. Manteufel, N.E. Todreas. Analytic formulae for the effective conductivity of a square or hexagonal array of parallel tubes // International Journal of Heat and Mass Transfer. 1994, N 37, p. 647657; DOI: 10.1016/0017-9310(94)90136-8.

9. M. Wataru, H. Takeda, K. Shirai, T. Saegusa. Thermal hydraulic analysis compared with tests of fullscale concrete casks // Nuclear Engineering and Design. 2008, N 238, p. 1213-1219;

DOI: 10.1016/j.nucengdes.2007.03.036.

10. S. Alyokhina, V. Goloshchapov, A. Kostikov, Yu. Matsevity. Simulation of thermal state of containers with spent nuclear fuel: multistage approach // International Journal of Energy Research. 2015, p. 1917-1924; DOI: 10.1002/er.3387.

11. V.G. Rudychev, M.O. Azarenkov, I.O. Girka, Y.V. Rudychev, O.P. Shchus. Contribution of radionuclides to heat release in the process of SNF dry storage // Problems of Atomic Science and Technology. Series "Physics of Radiation Effect and Radiation Materials Science”. 2017, N 2(108), p. 91-96.

12. S. Alyokhina, V. Goloshchapov, A. Kostikov, Y. Matsevity. Thermal state of ventilated concrete cask with spent nuclear fuel in the conditions of exterior airflow leaking // Nuclear Physics and Atomic Energy. 2009, p. 57-63.

13. S. Alyokhina, A. Kostikov. Unsteady heat exchange at the dry spent nuclear fuel storage // Nuclear Engineering and Technology. 2017, p. 1457-1462; DOI: 10.1016/j.net.2017.07.029.

14. S. Alyokhina, S. Kapuza, A. Kostikov. Solar Radiation Influence on the Spent Nuclear Fuel Dry Storage Container // Problems of Atomic Science and Technology. 2018, N 2, p. 57-62.

Article received 28.02 .2020 



\title{
НАУЧНЫЕ ОСНОВЫ АНАЛИЗА ТЕПЛОВОЙ БЕЗОПАСНОСТИ СУХОГО ХРАНИЛИЩА ОТРАБОТАВШЕГО ЯДЕРНОГО ТОПЛИВА ЗАПОРОЖСКОЙ АЭС
}

\author{
С. Алёхина, А. Костиков, И. Корягина
}

Сейчас в Украине эксплуатируется только одно сухое хранилище отработавшего ядерного топлива (СХОЯТ) - хранилище на Запорожской АЭС. Существует много исследований тепловых процессов в вентилируемых контейнерах СХОЯТ. В данной работе проведено обобщение научных подходов к оценке тепловой безопасности. Разработан многоуровневый подход к определению теплового состояния группы контейнеров, одиночных контейнеров, отработавших топливных сборок и топливных стержней. Рассчитаны детальные тепловые поля отработавших топливных сборок в середине контейнера для хранения. С использованием многоуровневого подхода было проведено тепловое моделирование и проанализировано влияние внешних факторов на тепловое состояние контейнеров. Результаты тепловых исследований были обобщены и выявлены факторы, которые влияют на тепловое состояние контейнеров. Предложен метод прогнозирования теплового состояния отработавшего ядерного топлива, и даны рекомендации по усовершенствованию системы теплового мониторинга.

\section{НАУКОВІ ОСНОВИ АНАЛІЗУ ТЕПЛОВОЇ БЕЗПЕКИ СУХОГО СХОВИЩА ВІДПРАЦЬОВАНОГО ЯДЕРНОГО ПАЛИВА ЗАПОРІЗЬКОЇ АЕС}

\author{
С. Альохіна, А. Костіков, І. Корягіна
}

Зараз в Україні експлуатується лише одне сухе сховище відпрацьованого ядерного палива (ССВЯП) сховище на Запорізькій АЕС. Існує багато досліджень теплових процесів у вентильованих контейнерах ССВЯП. У даній роботі проведено узагальнення наукових підходів до оцінки теплової безпеки. Розроблено багаторівневий підхід до визначення теплового стану групи контейнерів, одиничних контейнерів, відпрацьованих паливних збірок та паливних стрижнів. Розраховано детальні теплові поля відпрацьованих паливних збірок всередині контейнера для зберігання. 3 використанням багаторівневого підходу було проведено теплове моделювання та проаналізовано вплив зовнішніх факторів на тепловий стан контейнерів. Результати теплових досліджень були узагальнені та виявлені фактори, що впливають на тепловий стан контейнерів. Запропоновано метод прогнозування теплового стану відпрацьованого ядерного палива, та надані пропозиції що до вдосконалення системи теплового моніторингу. 